\title{
Evalution of the Microbiological Quality of Moroccan Cow Raw Milk in Dairy Herds Located in the Beni Mellal Region
}

\author{
Rachid Hnini, Lhou Ouhida, Mohammed Chigr, Mohamed Merzouki, Lahoucine Bahi, \\ Mohammed El Hansali, Mohamed Najimi, Fatiha Chigr
}

\begin{abstract}
The main objectives of the present study were to evaluate the microbiological quality of raw cow milk produced in Beni Mellal region, one of the major milk production areas in Morocco located in the North-Centre of Morocco to evaluate the characteristics of the raw milk produced and also to evaluate hygienic conditions effects and breeding factors on milk microbiological aspects. For this, hygienic quality of milk was determined by assessing the analysis of Total Aerobic Flora or Total Bacterial Count, Total Coliforms Count, Fecal Coliforms Count, Pseudomonas sp while germs such as Anaerobic Sulphite-reducing Bacteria, Staphyloccoccus aureus, Listeria monocytogenes and Salmonella sp, were carried out according to international standards. The analysis of the microbiological results found for all the areas investigated in this study revealed that the great majority of milk caw samples studied were contaminated but at diverse levels exceeding in many times the normal threshold. Absence of pathogenic flora mainly Salmonella sp, Clostridium and Listeria was revealed by the present investigations in agreement with numerous studies in Morocco. In order to reduce the strong microbial contamination of the caw milk samples studied, the industries and authorities must made a compensate system for farmers presenting a good hygienic milk criteria on the one hand and a penalties system for those providing a bad hygienic or chemical and physical milk criteria on the one other hand.
\end{abstract}

Index Terms- Milk, Microbiological Analysis, Hygienic quality, Pathogenic flora, Beni Mellal areas, Morocco.

Rachid Hnini, Laboratory of Biological Engineering, Pathology and Functional Biology Team, Sultan Moulay Slimane University, FST, PO.Box: 523, 23000 Beni Mellal, Morocco.

Lhou Ouhida, Laboratory of Biological Engineering, Pathology and Functional Biology Team, Sultan Moulay Slimane University, FST, PO.Box: 523, 23000 Beni Mellal, Morocco.

Mouhamed Chigr, Chemistry science department, Sultan Moulay Slimane University, FST, Beni Mellal, Morocco.

Mouhamed Merzouki, Laboratory of Biological Engineering, Pathology and Functional Biology Team, Sultan Moulay Slimane University, FST, PO.Box: 523, 23000 Beni Mellal, Morocco.

Lahoucine Bahi, Laboratory of Biological Engineering, Pathology and Functional Biology Team, Sultan Moulay Slimane University, FST, PO.Box: 523, 23000 Beni Mellal, Morocco,

Mouhamed El Hansali, Life science department, Sultan Moulay Slimane University, FST, Beni Mellal, Morocco.

Mouhamed Najimi, Laboratory of Biological Engineering, Pathology and Functional Biology Team, Sultan Moulay Slimane University, FST, PO.Box: 523, 23000 Beni Mellal, Morocco.

Fatiha Chigr, Laboratory of Biological Engineering, Pathology and Functional Biology Team, Sultan Moulay Slimane University, FST, PO.Box: 523, 23000 Beni Mellal, Morocco.

\section{INTRODUCTION}

In Morocco, dairy cattle production enjoys a very special status in agricultural development plans [1]. Indeed, it assumes a fundamental nutritional role of supplying animal proteins to an urban population in full demographic growth and whose eating habits evolve towards more quality products [2]. Thus, in order to ensure self-sufficiency in milk and its derivatives, Morocco has intensively and continuously encouraged milk production since the seventies of the last century (MADRPM, 1996) [3], to face demographical grow and its consequences [4, 5]. In order to ensure milk requirements, Morocco has for example promoted animal husbandry (purebred cows) through the organization of milk marketing channels through the establishment of dairy cooperatives [4]. Thus, since the launch of the dairy plan in 1975 (setting up of a production collection and processing structure), this sector has grown significantly from 521.6 million liters in 1975 to 2.6 billion liters in 2015 [6].

Furthermore, the development of this sector is in line with the goals of the new Moroccan agricultural strategy (the Moroccan Green Plan) for food self-sufficiency in horizon of 2020. It concerned seven basic alimentary products essential to the Moroccan diet where milk is an essential one [7]. For this reason, Morocco has re-launched the program-contract signed by the sector and the public authorities in 2015, which consequently foresees that the kingdom goes from a collection of 2.4 billion liters in 2013 to 4 billion in 2020, an increase of 1.55 billion liters compared to 2015 and a turnover of 23 billion dirhams [6]. This 2015-2020 national program-contract aims also to raise the average annual per capita consumption to 90 litres [6]. Similarly, dairy farming has significant social and economic roles in creating jobs and wealth in the many farms holding cows [8]. However, this challenge concerning the quantity of milk to produce poses the problem of the quality of the raw milk produced. Thus, if the produced quantities of milk are today in general satisfactory because of the great efforts made by Morocco in this context (encouraging milk production principally cow milk), various problems associated with quality standards, which are very hard to meet [1,9-13], still exist constituting a challenge for the agro-alimentary sector especially dairy industry in the county [14-15]. This concerns principally hygienic quality of the milk which could be altered by the presence of high levels of microorganisms (bacteria and at lesser degree molds). The analysis of the pathogenic flora in raw milk constitutes an important tool to evaluate this quality 
notably for raw milk destined to be processed. The bacteria enumeration reflecting the hygienic state of the milk such as Total Aerobic Mesophilic Flora, Faecal and Total Coliforms remains the most widely used method in dairy herds with the search for pathogenic germs such as Staphyloccocus aureus, Salmonella sp, Listeria monocytogenes and Anaerobic Sulfite-reducing Bacteria [14-15]. The main objectives of the present study were to evaluate the microbiological quality of raw cow milk produced in Beni Mellal region, one of the major milk production areas in Morocco located in the North-Centre of Morocco to evaluate the characteristics of the raw milk produced and also to evaluate hygienic conditions effects and breeding factors on milk microbiological aspects.

\section{MATERIAL AND METHODS}

\section{A. Sampling zones}

This work was performed in the irrigated perimeter of the West-North (area 1), North-West (area 2), West (area 3) and North (area 4) areas of Beni Mellal region (important milk production areas located in the north-central of Morocco (Figure 1). Almost of these areas (1, 2, 3 and 4) are situated in Tadla Plain located in central of Morocco. The plain parts are well developed and the agriculture is generally based on irrigation methods and many farms have developed their activities inside them. In some parts the community is more agropastoralist and there is large milk production from cows and goats [14-15].

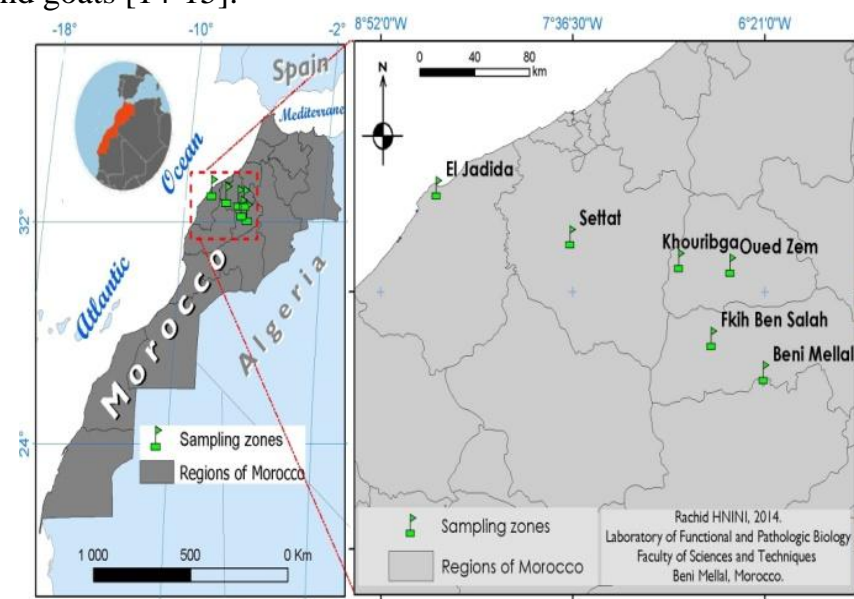

Figure 1: Presentation of sampling zones

\section{B. Sampling preparation}

A total of 100 samples raw milk was collected into sterile bottles (about $1000 \mathrm{ml}$ ) for physicochemical analysis and in the sterile flasks (about 50ml) for microbiological analysis from seventeen farms randomly selected in these areas already described and transported immediately in thermos-cool boxes (at $4^{\circ} \mathrm{C}$ ) to Biological Engineering Laboratory, Sultan Mouly Slimane University during a period extended from January to June. All sampling operations have been made at the morning and afternoon milking times and all hygienic analyses were directly determined on the day of sampling.

\section{Microbiological analysis}

The raw milk samples destined to microbiological analysis were taken in sterile flasks and transported immediately using an insulated cooler containing ice cubes at $-18^{\circ} \mathrm{C}$ (thermos-cool boxes (at $4^{\circ} \mathrm{C}$ )) and in the dark to ensure permanent samples at a temperature between 0 and $4^{\circ} \mathrm{C}$ to block the multiplication of bacteria already present in the milk according to the rules of sampling proposed by the milk committee to the laboratory for microbiological analyzes. Dilutions of milk samples studied were performed in peptone water and varied from $10-1$ to $10-6$. The isolation and enumeration of bacteria reflecting hygienic degree such as Total Aerobic Flora, Total Coliforms, Fecal Coliforms and germs such as Anaerobic Sulphite-reducing Bacteria, Staphylococcus aureus, were carried out according international standards [18].

Bacteria enumeration: The non-selective culture medium Plate Count Agar (PCA) was used for counting of Total Aerobic Flora (the incubation conditions were $72 \mathrm{~h}$ at $30^{\circ} \mathrm{C}$ ). Moreover, the Desoxycholate Lactose Agar (DL, Oxoid, England), a selective medium for the detection of enterobacteriacea was used for enumeration of coliforms (the incubation was operated during $48 \mathrm{~h}$ at $30^{\circ} \mathrm{C}$ for Total Coliforms and $44^{\circ} \mathrm{C}$ for Fecal Coliforms). For the Salmonella sp. estimation, the Rappaport-Vassiliadis broth was utilized $\left(24 \mathrm{~h}\right.$ at $\left.42^{\circ} \mathrm{C}\right)$ and Hektoen medium $\left(24 \mathrm{~h}\right.$ at $\left.30^{\circ} \mathrm{C}\right)$ whereas the confirmation of identification of suspect colonies was made by the aid of API20 E kit (Biomérieux, France). The detection of Listeria monocytogenes was performed by using broth Frazer $\left(24 \mathrm{~h}\right.$ at $\left.37^{\circ} \mathrm{C}\right)$ while the confirmation of suspect colonies was performed by the use of chromogenic medium with the API Listeria. Concerning the estimation of Staphylococcus aureus, the incubation of diluted milk samples was made in Baird Parker media at $37^{\circ} \mathrm{C}$ during $48 \mathrm{~h}$ [14-15]. Finally, the Sulphite-reducing Clostridia are counted on the Reiforced Clostridium Agar culture medium in tubes to favor the anaerobic conditions, with a heat treatment for 10 min at $80^{\circ} \mathrm{C}$ to activate the spores of Clostridia: they can persist in latent form in the milk, sprout as soon as conditions are favorable and secrete toxic substances. The tubes are incubated for $48 \mathrm{~h}$ at $37^{\circ} \mathrm{C}$. Only black colonies are counted [19].

\section{RESULTS}

The essential of obtained results of the microbiological analysis of raw cow's milk produced in different studied areas are presented in Table $\mathbf{1 .}$ 
Table 1: Microbiological analyzes average of raw milk obtained from different areas in Beni Mellal.

\begin{tabular}{|c|c|c|c|c|c|c|c|c|}
\hline \multirow[b]{3}{*}{ Studied areas } & \multicolumn{8}{|c|}{ Microbiological analysis (UFC/ml) } \\
\hline & \multicolumn{2}{|c|}{$\begin{array}{l}\text { Total Coliform } \\
\text { (TC) }\end{array}$} & \multicolumn{2}{|c|}{$\begin{array}{l}\text { Fecal Coliform } \\
\text { (FC) }\end{array}$} & \multicolumn{2}{|c|}{\begin{tabular}{|l|} 
Total Aerobic \\
Flora (TAF)
\end{tabular}} & \multirow{2}{*}{\begin{tabular}{|l|}
$\begin{array}{l}\text { Pseudo-mona } \\
\text { s }\end{array}$ \\
$10(-6)$
\end{tabular}} & \multirow{2}{*}{$\begin{array}{l}\text { S. aureus } \\
1 \mathrm{ml}\end{array}$} \\
\hline & $10(-3)$ & $10(-4)$ & $10(-3)$ & $10(-4)$ & $10(-5)$ & $10(-6)$ & & \\
\hline Area 1 & 77,50 & 29,30 & 42,20 & 20,60 & 49,20 & 8,90 & 2,50 & 39 \\
\hline Area 2 & 97,20 & 29,90 & 51,70 & 21,00 & 101,40 & 19,80 & 5,10 & 591 \\
\hline Area 3 & $>300$ & 77,20 & $>300$ & 104,6 & 123,20 & 18,20 & 15,90 & 372 \\
\hline Area 4 & 188.4 & 35,10 & 135,43 & 24,30 & 133,40 & 22,10 & 12,50 & 854 \\
\hline
\end{tabular}

The analysis of the microbiological results found for all the areas investigated in this study revealed that the great majority of milk caw samples studied were contaminated but at diverse levels. Indeed, the enumeration of Fecal and Total Coliforms (FC an TC), in West-North, North-West, West and North areas of Beni Mellal region (area 1, 2, 3 and 4), showed average values of $2 \times 10^{5}, 2.1 \times 10^{5}, 1 \times 10^{6}$ and $2.4 \times$ $10^{5} \mathrm{UFC} / \mathrm{ml}$ (FC) and $2.9 \times 10^{5}, 3 \times 10^{5}, 7.7 \times 10^{5}$ and $3.5 \times$ $10^{5} \mathrm{UFC} / \mathrm{ml}$, respectively for TC. When the Pseudomonas sp count was considered, the levels are in the range of $2.5 \times 10^{6}$, $5.1 \times 10^{6}, 1.5 \times 10^{7}$ and $1.2 \times 10^{7} \mathrm{UFC} / \mathrm{ml}$, in areas $\mathbf{1}, \mathbf{2}, 3$ and 4, respectively. Moreover, the enumeration of Total Aerobic Flora (TAF) showed the following values: $9 \times 10^{6}, 2 \times 10^{7}$, $1.8 \times 10^{7}$ and $2.2 \times 10^{7} \mathrm{UFC} / \mathrm{ml}$.

Concerning the remaining pathogenic group bacteria analyzed in this study such as Salmonella sp, Listeria monocytogenes, Clostridium we noticed their absence in all tested samples and in all studied areas, except for Staphylococcus aureus showing mean content of 39, 591, 372 and $854 \mathrm{UFC} / \mathrm{ml}$ in areas $\mathbf{1 , 2}, \mathbf{3}$ and 4, respectively.

\section{DISCUSSION}

In general, the rational feeding of dairy cows has a major influence on both the quantitative and quality production of milk for industrial uses. The value or industrial quality of milk can be expressed by all the properties and physicochemical, biological and organoleptic characteristics required for ensure the production of high value dairy products commercial [20]. Milk, by its composition and by the different routes that it can undergo before its use either by the processor or by the consumer, constitutes a vector of transmission of microbes, which are generally opportunistic and sometimes harmful or even pathogenic [21].

The findings obtained by enumeration of different microbial flora of raw caw milk samples in West-North, North-West, West and North areas of Beni Mellal region (areas 1, 2, 3 and 4) are cited in Table 1. The analysis of the microbiological results found for all the areas investigated in this study revealed that the great majority of milk caw samples studied were contaminated but at diverse levels. Indeed, the enumeration of Fecal and Total Coliforms (FC and TC) showed an average of $2 \times 10^{5}, 2.1 \times 10^{5}, 1 \times 10^{6}$ and
$2.4 \times 10^{5} \mathrm{UFC} / \mathrm{ml}$ and about $2.9 \times 10^{5}, 3 \times 10^{5}, 7.7 \times 10^{5}$ and $3.5 \times 10^{5} \mathrm{UFC} / \mathrm{ml}$, respectively; whereas the Pseudomonas sp count showed values corresponding to $2.5 \mathrm{x}$ $10^{6}, 5.1 \times 10^{6}$,

$1.5 \times 10^{7}$ and $1.2 \times 10^{7} \mathrm{UFC} / \mathrm{ml}$, recorded respectively in areas 1, 2, 3 and 4. Moreover, the enumeration of Total Aerobic Flora (TAF) was about $9 \times 10^{6}, 2 \times 10^{7}, 1.8 \times$ $10^{7}$ and $2.2 \times 10^{7} \mathrm{UFC} / \mathrm{ml}$, respectively in these cited above areas. These findings show strong microbial contamination of the caw milk samples studied.

The total bacteria count was more important in West and North areas of Beni Mellal region (area 3 and area 4) compared to other areas analyzed in this study. This could be associated to non-compliance with hygienic conditions and rules during production and milking as well as lack of refrigeration during milk storage and transportation to the processing industrial unit [22]. Our findings remain generally equivalent to findings recently reported by Ferdous et al.[14-15] in proximal areas to Beni Mellal city (Fecal Coliforms: $10^{4}$ to $10^{5}$; Total Coliforms: $7.3 \times 10^{4}$ to $6.49 \times 10^{5}$ and Total Aerobic Flora: $10^{5}$ to $\left.5 \times 10^{6} \mathrm{UFC} / \mathrm{ml}\right)$. In Beni Mellal region ([14-15], but contrast with these results showing marked variations in the microbial charge when season is taken into account. Adding to that, during March to June; Afif et al.[12-13] showed previously in the same area of Beni Mellal a load amount ranged from $0.1 \times 10^{5}$ to $3.2 \times 10^{5}$, $0.4 \times 10^{3}$ to $4.6 \times 10^{3}$ and $1.1 \times 10^{6}$ to $11.4 \times 10^{6} \mathrm{UFC} / \mathrm{ml}$ for Total Coliforms, Fecal Coliforms and Total Aerobic Flora; respectively. These results remain slightly lesser than those reported in this study indicating that this difference in charge may be due to non-respect of hygiene conditions.

The findings of this study corroborate several previous analyses reported in other regions in Morocco characterized with high levels of coliforms present in raw milk [4]. In this regard, a moderate lesser load amount of Total Coliforms, Fecal Coliforms and Total Aerobic Flora $\left(2 \times 10^{4}, 5.2 \times 10^{3}\right.$, $7.4 \times 10^{6} \mathrm{UFC} / \mathrm{ml}$ ) was respectively described in the Mnasra region in Morocco [19] when compared to that found in this study. Moreover, an equivalent load amount of Total Aerobic Flora was reported by Srairi et al.[1] in Rabat-Sale region (1.2 $\left.10^{7} \mathrm{UFC} / \mathrm{ml}\right)$. The levels of Total Aerobic Flora, Fecal Coliforms and Total Coliforms in all the regions analyzed in this study rest less than reports previously described by 
Ounine et al.[9] in Gharb region $\left(1.23 \times 10^{8}, 1.07 \times 10^{7}\right.$ and $1.99 \times 10^{7} \mathrm{UFC} / \mathrm{ml}$, respectively). This increase in milk load reflects also problems in the procedures used during milking and those related to cleaning equipment which seem to be inadequate [23-24].

Concerning the remaining pathogenic group bacteria analyzed in this study such as Salmonella sp, Listeria $\underline{\text { monocytogenes, }}$ Clostridium and $\underline{\text { Staphylococcus aureus, }}$ these bacteria were considered to constitute the main dangerous pathogens to humans. Generally, our raw milk samples indicate a total absence of Salmonella sp, Listeria

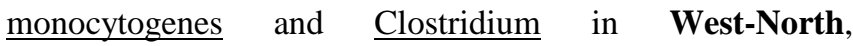
North-West, West and North areas of Beni Mellal region (area 1, 2, 3 and 4). Concerning the average content of Staphylococcus aureus, another dangerous pathogen, it corresponds to $39,591,372$ and $854 \mathrm{UFC} / \mathrm{ml}$ recorded respectively in areas 1, 2,3 and 4. These values are lesser than values reported previously by Afif et al.[12-13] (0.8 to $5 \mathrm{x}$ $103 \mathrm{UCF} / \mathrm{ml})$ and Ferdous et al.[14-15] (>103 UCF/ml) in Tadla plain and in Beni Mellal region, respectively. Furthermore, our results show low loads compared to other Moroccan regions notably in the Gharb regions $\left(9 \times 10^{4}\right.$ $\mathrm{UCF} / \mathrm{ml}$ [25]; 5 x $105 \mathrm{UCF} / \mathrm{ml}$ [26], and in the Rabat region (25 x $105 \mathrm{UCF} / \mathrm{ml}$; Hamama[27] indicating that numerous efforts have been made to reduce threshold of the milk Staphylococcus aureus load and by consequent ameliorating the quality of hygienic milk in Beni Mellal region.

Staphylococcus aureus, is a bacteria that is easily transmitted from one cow to another, is often responsible for triggering subclinical mastitis. For this reason, it is strongly recommended that the teat cups must be rinsed and disinfected after milking an infected cow. It is also advisable to spray the teats after milking with a certified soaking solution. Our negative findings for Salmonella sp, Listeria $\underline{\text { monocytogenes and Clostridium are similar to previous }}$ findings reported for Beni Mellal region [12-15] and in other Moroccan regions [12-15, 25].

Concerning Maghreb countries, our findings show also differences with reports in Tunisia and Algeria areas, principally in case of Clostridium and Staphylococcus aureus prevalence that was in the range of $2.87 \%$ and $24.71 \%$ respectively in Tizi Ouzou region [28]. Moreover, in Oran region (west Algeria), a load of $72.3 \times 10^{5}, 8.4 \times 10^{5}, 9.8 \times 10^{4}$ and $19.4 \times 10^{5} \mathrm{UFC} / \mathrm{ml}$ was recorded in Sidi Bachir area for Total Mesophelic Aerobic Flora, Fecal coliforms, Clostridium perfringens and Staphylococcus aureus, respectively; whereas a level load of $27.1 \times 10^{2}, 3.6 \times 10^{4}, 2.7$ $\mathrm{x} 10^{4}$ and $0 \mathrm{UFC} / \mathrm{ml}$ was recorded in Gdyel area for the same germs. Moreover, a level of $38 \times 10^{4}$ was observed in case of Messerghine area and a load of $2.1 \times 10^{2} \mathrm{UFC} / \mathrm{ml}$ was described in Fleurus area [29]. Finally, Kaouche et al.[30] showed, in Boumerdes area in Algeria, a significant differences in the profiles of various studied microbial pathogens indicating the presence of a deterioration in the microbiological quality of raw milk (Listeria: 13\%, Staphylococcus aureus: $23 \%$, Sulphite-reducing Clostridia: $30 \%)$.

\section{CONCLUSION}

The analysis of the microbiological findings in all the areas investigated in this study revealed that the great majority of milk cow samples studied were contaminated but at diverse levels exceeding in many times the normal threshold, supporting the assumption that all these herds were confronted to problems in milking hygiene (this could be associated to the conditions of raw milk handling, practices during milking, storage and transportation especially in West and North areas of Beni Mellal (area 3 and 4). Absence of pathogenic flora mainly Salmonella sp, Clostridium and Listeria monocytogenes revealed that the milk produced does not present high danger for consumers. In order to reduce the strong microbial contamination of the cow milk samples studied, the industries and authorities must made a compensate system for farmers presenting a good hygienic milk criteria on the one hand and a penalties system for those providing a bad hygienic or chemical and physical milk criteria on the one other hand.

\section{ACKNOWLEDGMENT}

This work is supported by scientific research council of Sultan Moulay Slimane University.

\section{TRANSPARENCY DECLARATIONS}

None to declare.

\section{REFERENCES}

[1] Srairi, M.T., Hasni Alaoui, I., Hamama, A. et Faye, B. 2005. Relations entre pratiques d'élevage et qualité globale du lait de vache en étables suburbaines au Maroc. Revue Méd.Vét. 156 (3) : 155-162.

[2] El khayari, T. 1985. Agriculture au Maroc. Ed. Okad, Casablanca. p500.

[3] Le Gal, P., Kuper, M., Moulin, C., Puillet, L., Sraïri, M.T. 2007. Dispositifs de coordination entre industriel, éleveurs et périmètre irrigué dans un bassin de collecte laitier au Maroc. Cahiers Agricultures, 16: 265-271.

[4] Bassbasi, M., Hirri, A., Oussama, A. 2013. Caractérisation physico chimique du lait cru dans la région de Tadla-Kelaa au Maroc: Application de l'analyse exploratoire. International Journal of Innovation and Applied Studies, ISSN 2028-9324, 2: 512-517.

[5] Bousselmi, K. Djemali, M., Bedhiaf, S., Hamrouni, A. 2010. The Factors affecting milk fat and protein of dairy cattle in Tunisia. Renc. Rech. Ruminants, 17: 399.

[6] Belkadi, N. 2016. Directeur de 1'Association nationale des éleveurs bovins, membre de la Fédération Fimalait, pendant la 11ème édition du Salon international de l'agriculture au Maroc (SIAM) qui se déroulait à Meknès, Maroc.

[7] Sayouti, S.N., Ait El Mekki, A. 2015. Le Plan Maroc Vert et l'autosuffisance alimentaire en produits de base à l'horizon 2020 . Alternatives Rurales (3).

http://alternativesrurales.org/wpcontent/uploads/Numero3/AltRur3PM VetAutosuffisanceAli entairePourImp.pdf (access date: 17.11.17)

[8] Akesbi, N. 1997. La question des prix et des subventions au Maroc face aux mutations de la politique agricole. Options Méditerranéennes, Série $B, n^{\circ} 11$, Prix et subventions : effets sur les agricultures familiales méditerranéennes. p. 81-117.

[9] Ounine, K., Rhoutaisse, A. and El Halou, N.E. 2004. Caractérisation bactériologique du lait cru produit dans les étables de la région du Gharb. Al awamia, 109-110: 187-204.

[10] Taybi, N.O., Arfaoui A., Fadli M. 2014. Evaluation of microbiological quality of raw milk in the region of Gharb, Morocco. International Journal of Innovation Science and Research, 9; 487-93.

[11] Mchiouer, K,. Bennani, S,. El-Gendy, N.S., Meziane, M. 2017. Evaluation of the hygienic quality of raw cow's milk in Oujda city Morocco. Biosciences Biotechnology Res Asia, 14: 587-91. 
[12] Afif, A., Faid, M., Najimi, M. 2007. Effects of breeding and hygienic practices on raw cow milk quality in Tadla area, Morocco. Livestock Research for Rural Development, 19 (12).

[13] Afif, A., Faid, M., Najimi, M. 2008. Qualité microbiologique du lait cru produit dans la région de Tadla au Maroc. Reviews in Biology and Biotechnology, 7: 2-7

[14] Ferdous, N,. Hnini, R., Chigr, F,. Najimi, M. 2017. Hygienic Quality of Raw Cow Milk Produced by Smallholder Dairy Farmers in Beni Melle area in Morocco. World Journal of Research and Review (WJRR), 5: 09-16.

[15] Ferdous, N., Hnini, R., Merzouki, M., Bahi, L., Chigr, F., Najimi, M. 2017a. Microbiological Characteristics of Raw Cow Milk in Beni Mellal Area (Morocco). International Journal of Science and Engineering Applications, Volume 6 Issue 10, ISSN-2319-7560.

[16] Cherkaoui, F.Z., El Iamani, A., El Mansouri, L. 2004. Développement et pratique de la fertigation dans le périmètre irrigué du Tadla. IPI regional workshop on Potassium and Fertigation development in West Asia and North Africa; Rabat, Morocco.

[17] El Harti, A., Lhissou, R., Chokmani, K., Ouzemou, J., Hassouna, M. Bachaoui, E., El Ghmari, A. 2016. Spatiotemporal monitoring of soil salinization in irrigated Tadla Plain (Morocco) using satellite spectral indices. International Journal of Applied Earth Observation and Geoinformation, 50: 64-73.

[18] ICMSF. 1986. Microorganisms in Foods 2. Sampling for Microbiological Analysis: Principles and Specific Applications. 2nd Edn., University Toronto Press, Canada.

[19] Labioui, H., El moualdi, L., Ben zakour, A., El yachioui, M., Berny, E., Ouhssine, M. 2009. Étude physicochimique et microbiologique de lait. Bulletin de la Société de pharmacie de Bordeaux , 148: 7-16.

[20] Bérard, H.L., Rosell, J.M., Turgeon, J. 1936. L'influence de l'alimentation des vaches laitières sur la production de lait de bonne qualité industrielle. Le Lait, INRA Editions, 16 (160), pp.1068-1083. $<$ hal-00895258>

[21] Leite, C.Q.F., Anno, I.S., Nogima, L.Y.,Umbelino, D.c., Mello, S.R.D. Bacteriologicqaul qality of milk and pasreurised milk in Araraquara $S$ P, Brasil. Revistade Ciencias Farmaceuticas, 16: 137-145.

[22] Ismaili, A. M., Saidi, B., Zahar, M., Hamama, A., Ezzair, R. 2016. Composition and microbial quality of raw camel milk produced in Morocco. Journal of the Saudi Society of Agricultural Sciences. Doi.org/10.1016/j.jssas.2016.12.001

[23] Desmasures, N., Guéguen, M. 1997. Monitoring the microbi- ology of high quality raw milk by sampling over two years. Journal of Dairy Research 64, 271-280.

[24] Ksontini, H., Kachouri, F., Hamdi, M. 2011. Microflora distribution and assessment of microbiological quality milk from Tunisian collection centers. African Journal of Micro- biology Research. 5 : 1484-1491.

[25] Riahi, N. 1981. Contribution à l'étude de la qualité bactériologique des centres de collecte dans la région du Gharb. Thèse pour le doctorat vétérinaire, Institut Agronomique et Vétérinaire Hassan II, Rabat, Maroc.

[26] Hadrya, F., AElouardi, D., Benali, H., Hami, A., Soulaymani, S. 2012. Bacterial Quality of Informally Marketed Raw Milk in Kenitra City, Morocco. Pakistan Journal of Nutrition, 11: 8; 760-767.

[27] Hamama, A. 2002. Hygiène et prophylaxie dans les étables laitières .cours de Formation des techniciens de l'office régionale de Mis en valeur agricole L'haouz.Marrkech. pp 10-25, 62-71,80-110.

[28] Titouche, Y., Hakem, A., Salmi, D., Yabrir, B., Chenouf, N., Chergui, A., Chenouf, A., Houali, K. 2016. Assessment of Microbiological Quality of Raw Milk Produced at Tizi Ouzou Area (Algeria). Asian Journal of Animal and Veterinary Advances, 11: 854-860. Doi: 10.3923/ajava.2016.854.860

[29] Benlahcen, K., Mouloudi, F., Kihal, M. 2013. Study of the microbiological and physicochemical quality of raw milk from cows exposed to environmental pollutants in the region of West Algeria. International Journal of Environmental Engineering Science and Technology Research, 1: 229-240, Available online at www.ijestr.org

[30] Ouchene-Khelifi, N.A., Lafri, M., Ferrouk, M., Ouchene, N. Physicochemical analysis of raw milk of Prim'holstein cows in the region of Mitidja in Algeria. 